\title{
Variability in the Functional Activity of Vaccine- Induced Antibody to Haemophilus influenzae Type b
}

\author{
JACOB AMIR, XIAYUAN LIANG, AND DAN M. GRANOFF \\ Edward Mallinckrodt Department of Pediatrics, Washington University School of Medicine, and the Division of \\ Infectious Diseases, St. Louis Children's Hospital, St. Louis, Missouri 63110
}

\begin{abstract}
Sera from 3 of 30 adults vaccinated with Haemophilus influenzae type b polysaccharide vaccine (Hib PS) had poor complement-mediated bactericidal activity despite the presence of anti-Hib PS antibody concentrations of 8.6 to $20.5 \mu \mathrm{g} / \mathrm{mL}$. These "nonkiller" antibodies killed $<0.4 \log \mathrm{cfu} / \mathrm{mL}$ compared to $>3 \operatorname{logs}$ with all but one of the other sera. To investigate the basis of this poor functional activity, we characterized in detail the IgG antibodies to Hib PS present in two of the nonkiller sera, and compared the results with two of the "killer" sera. The latter were selected based on comparable levels of total antibody to Hib PS. No consistent differences were found between the relative proportions of $\operatorname{IgG}$ or $\operatorname{IgA}$ antibody to total anti-Hib PS antibody, or the respective ratios of IgG1 to IgG2 antibody in the nonkiller and killer sera. IgG fractions, and IgG affinity purified antibody to Hib PS were prepared. When tested at $2 \mu \mathrm{g} / \mathrm{mL}$ of antibody, the IgG fractions from the two nonkiller sera had much lower bactericidal activity than the corresponding fractions from the killer sera ( 3 logs less killing), and the former also had lower complement-mediated opsonic activity (20 and $13 \%$ uptake by human PMN compared to 62 and $93 \%$ ). These data show the striking variability in the functional activity of vaccine-induced antibody to $\mathrm{Hib}$ PS. Antibody functional activity is likely to be affected by a number of factors but one important variable appears to be avidity since the IgG anti-Hib PS antibody from the two nonkiller sera had 2to 5-fold lower avidity than the IgG antibody from the two killer sera. Therefore, measurement of antibody avidity in studies of Hib vaccine immunogenicity would be informative (Pediatr Res 27: 358-364, 1990)
\end{abstract}

\section{Abbreviations}

Hib PS, Haemophilae influenze type b polysaccharide NK, nonkiller

$\mathrm{K}$, killer

RABA, radioantigen binding assay

VBS, veronel-buffered saline

PMN, polymorphonuclear leukocyte

cfu, colony-forming unit

Serum antibody to Hib PS confers protection against Hib disease by activating complement-dependent bacteriolysis and/ or opsonization (1). The antibody concentration sufficient to

Received September 7, 1989; accepted December 11, 1989.

Correspondence: Dan M. Granoff, M.D., Department of Pediatrics, 400 South Kingshighway Blvd., St. Louis, MO 63110.

Supported by U.S. Public Health Grants R01 AI 17962 and R01 AI 21842 from the National Institute of Allergy and Infectious Diseases, NIH. confer protection is not known with certainty but based on epidemiologic and animal studies, it is estimated to be between 0.1 and $1.0 \mu \mathrm{g} / \mathrm{mL}$ of total anti-Hib PS antibody as measured by Farr-type antigen-binding assays (2-6). One problem in determining a "protective" antibody concentration is that there is variability in the isotype distribution of antibody among individuals, and it is possible that different isotypes differ in their ability to confer protection (7). Also, antibodies of the same isotype may have different functional activity as a result of differences in antibody avidity $(8,9)$ or fine antigenic specificity $(10)$.

Previous studies have attempted to predict the protective efficacy of vaccination by correlating serum antibody concentrations to Hib PS with measurements of antibody functional activity such as complement-mediated bacteriolysis (11-17), or opsonization (17-20). The results suggest that the magnitude of the serum antibody concentration after vaccination correlates with in vitro functional activity $(12,15,16,19,20)$. However, there are notable exceptions, and some individuals respond to vaccination with antibodies that have relatively poor bactericidal (12, $15,16)$ or opsonic activity (19). The purpose of our study was to investigate the basis of the differences in functional activity of serum antibody evoked in adults by immunization with Hib PS vaccine. Adults were selected because of the large volumes of sera required for these studies. However, by defining the factors affecting antibody functional activity in the sera of immunized adults it should be possible in the future to perform similar investigations of serum antibodies from immunized infants.

\section{MATERIALS AND METHODS}

Human sera. Thirty adults were immunized with $25 \mu \mathrm{g}$, s.c., of Hib PS vaccine (Praxis Biologics, Inc., Rochester, NY). Sera were obtained 1 to 2 mo later and screened for bactericidal activity using $20 \%$ heat-inactivated serum, an inoculum of $\sim 10^{6}$ $\log$-phase organisms and $20 \%$ agammaglobulinemic serum as a complement source. Details of the bacterial strains used and assay conditions are described below. Four subjects had poor complement-mediated serum bactericidal activity. One of the four sera had $3.5 \mu \mathrm{g} / \mathrm{mL}$ of antibody to Hib PS and was not characterized further. Two of the remaining three sera were characterized in detail. They contained 20.5 and $9.2 \mu \mathrm{g} / \mathrm{mL}$ of antibody to Hib PS, and killed $<0.4 \log \mathrm{cfu} / \mathrm{mL}$ of Hib compared to $>3$ logs with the other 26 sera. The antibodies of the two adults were designated as NK. Sera obtained from the two NK adults 12 to 20 mo after vaccination still failed to kill $\mathrm{Hib}$ and were used in the studies described below. Sera obtained from two additional adults 14 mo after vaccination were selected based on the presence of bactericidal activity ( $>3.5$ logs killing), and levels of anti-Hib PS antibody comparable to those measured in the two NK sera (antibodies in these control sera were designated $\mathrm{K})$.

Serology. Except where noted, the concentrations of total anti- 
Hib PS antibody were measured by a RABA previously described $(21,22)$. This assay uses $50 \mu \mathrm{L}$ of test sample diluted to a final vol of $500 \mu \mathrm{L}$, and polyethylene glycol radioimmune precipitation. ${ }^{125} \mathrm{I}$-Hib PS $\left(\mathrm{k}_{d}=0.68\right.$ on Sepharose $\left.2 \mathrm{~B}\right)$ was used as the test antigen. A previously described solid phase ELISA was used to measure $\operatorname{IgA}, \operatorname{IgG}, \operatorname{IgG} 1$, and IgG2 anti-Hib PS antibody $(22$, 23). The IgG and IgA were detected using biotin conjugated goat anti-human IgG antibody, $\gamma$-chain specific (1:5000), or antihuman IgA, $\alpha$-chain specific (1:2500), (Tago, Inc., Burlingame, $\mathrm{CA}$ ), with avidin-alkaline phosphatase. The anti-IgG1 reagent was monoclonal antibody HG11 (24). To detect IgG2 antibodies, a mixture of two MAb, HP6014 (diluted 1:20 000) and HP6008 (1:1000) from ICN Immunologics (Lisle, IL), was used. This combination permitted optimal sensitivity while minimizing the $\lambda$-light chain preference of HP6014 (25). The concentrations of IgA anti-Hib PS were determined from a standard curve of the Office of Biologics Hib reference serum pool (Food and Drug Administration, Bethesda, MD). This serum pool tentatively has been assigned a value of $5.6 \mathrm{U} / \mathrm{mL}$ of $\mathrm{IgA}$ antibody with each unit representing approximately $1 \mu \mathrm{g}$ of protein (26). IgG, IgG1, and $\mathrm{IgG} 2$ values were expressed in $\mu \mathrm{g} / \mathrm{mL}$ as previously described (23).

Preparation of $\operatorname{Ig} G$ fraction. $\mathrm{IgG}$ fractions were prepared by gel-filtration on Sephacryl S-300 (Pharmacia Fine Chemicals, Uppsala, Sweden). The anti-Hib PS antibody concentrations in the fractions were determined by class-specific ELISA (see above). IgG fractions with no detectable IgA or IgM antibody were pooled and concentrated by ultrafiltration with an Amicon PM 30 Diaflo filter (Amicon Corp., Danvers, MA). The portion of IgG used for measurement of bactericidal activity was dialyzed against VBS containing $8.5 \mathrm{~g} \mathrm{NaCl}, 0.46 \mathrm{~g}$ sodium salt of barbitol, $0.51 \mathrm{~g}$ barbituric acid/liter ( $\mathrm{pH} 7.4$ ). After dialysis, the $\mathrm{IgG}$ was sterilized using a syringe filter $(0.2 \mu \mathrm{m}$, Gelman Science Inc., Ann Arbor, MI), and the antibody concentrations were measured by RABA.

Preparation of affinity purified anti-Hib PS antibody. The IgG fractions were incubated with an affinity matrix containing Hib PS that had been prepared according to the method of Kuo (27), and then coupled to aminohexyl Sepharose 4B (Pharmacia Fine Chemicals) using cyanogen bromide as described (28). The affinity-purified anticapsular antibody was eluted with $3.5 \mathrm{M} \mathrm{MgCl}_{2}$, immediately diluted $1: 2$ in VBS-BSA, and then dialyzed against VBS. The fractions were concentrated to approximately the original serum concentration of IgG anti-Hib PS antibodies, filter sterilized, and reassayed by RABA.

Bacteria. Two Hib test organisms were used, strains Eagan (11) and MinnA (29). Both are fully encapsulated type b organisms originally obtained from patients with invasive Hib disease. Strain Eagan has the outer membrane protein subtype $1 \mathrm{~L}$ (30), and MinnA has the outer membrane protein subtype $1 \mathrm{H}$. The latter isolate is representative of the most common clonal group of Hib currently causing disease in the United States (30, 31 ), whereas, the former, isolated in 1968 (11), is representative of a strain prevalent in the United States between 1940 and 1954 $(32,33)$. The two isolates have been maintained frozen at $-70^{\circ} \mathrm{C}$ in skim milk in multiple vials. Both isolates are resistant to killing by complement alone, and are highly virulent in the infant rat model of bacteremia $(13,14,34)$.

Bactericidal assay. Complement-mediated bactericidal activity was measured as previously described (16), except that VBS-BSA was used instead of Hanks' balanced salt solution with $0.1 \%$ gelatin. The reaction mixture had different concentrations of antibody, and a final concentration of $20 \%$ agammaglobulinemic serum as the complement source (13), log-phase Hib cells (strain Eagan or MinnA at $\sim 10^{6} \mathrm{cfu} / \mathrm{mL}$ in VBS-BSA except as noted), and $0.15 \mathrm{mM} \mathrm{CaCl}_{2}$ and $0.50 \mathrm{mM} \mathrm{MgCl}_{2}$. The final volume was $120 \mu \mathrm{L}$. The reaction vials were incubated at $37^{\circ} \mathrm{C}$ in a shaking water bath ( 100 cycles/min) for $60 \mathrm{~min}$, and serial dilutions were plated on chocolate agar plates. Bactericidal titers were defined as the log decrease in $\mathrm{cfu} / \mathrm{mL}$ compared to that present prior to incubation (time 0 ).

Opsonophagocytosis assay. Enhancement of phagocytosis by affinity purified anti-Hib PS antibodies and complement was investigated by measuring uptake of $\left[{ }^{3} \mathrm{H}\right]$ thymidine-labeled Hib cells by human PMN as previously described (18). In brief, a loop full of Hib strain MinnA from an overnight growth on a chocolate plate was inoculated into $20 \mathrm{~mL}$ of Trypticase soy broth (BBL Microbiology System, Cockeysville, MD) supplemented with $15 \mu \mathrm{L} / \mathrm{mL}$ of methyl- $\left.{ }^{3} \mathrm{H}\right]$ thymidine (sp act, $50-80$ $\mathrm{Ci} / \mathrm{mmol}$; New England Nuclear Corp. Boston, MA), and NAD and hemin, each at $10 \mu \mathrm{g} / \mathrm{mL}$. The bacteria were grown for about $1.5 \mathrm{~h}$ to an OD of $0.35-0.45$ at $600 \mathrm{~nm}$. They were washed twice in VBS-BSA supplemented with $0.15 \mathrm{mM} \mathrm{CaCl}_{2}$ and 0.50 $\mathrm{mM} \mathrm{MgCl}_{2}$ (designated VBS-BSA ${ }^{++}$) and resuspended in VBSBSA (no added $\mathrm{Ca}$ or $\mathrm{Mg}$ ) to a final concentration of approximately $2 \times 10^{9} \mathrm{cfu} / \mathrm{mL}\left(5-7 \times 10^{6} \mathrm{cpm} / \mathrm{mL}\right)$. Radiolabeled $\mathrm{Hib}$ $\left(2 \times 10^{8} \mathrm{cfu} / \mathrm{mL}\right)$ were preopsonized with different concentrations of affinity-purified anti-Hib PS antibody, and 25\% complement in a final volume of $250 \mu \mathrm{L}$. The complement source was the same agammaglobulinemic serum as used in the bactericidal assay described above. To minimize complement-mediated bacteriolysis in the opsonic assay, preopsonization was performed in VBS-BSA ${ }^{++}$supplemented with $0.2 \%$ glucose and $5 \%$ Bacto Fildes Enrichment (Difco Laboratories, Detroit, MI) as described (35).

One healthy adult donor was used as a source of PMN. The PMN were separated from peripheral blood by dextran sedimentation followed by centrifugation over lymphocyte separation media (Bionetics Laboratory Products, Kensington, MD) (18). For purposes of calculation, uptake of control Hib preopsonized with complement and $10 \%$ immune serum pool was assumed to yield $100 \%$ uptake because it approached the upper limit of uptake of the assay (18). The undiluted immune pool contained $164 \mu \mathrm{g} / \mathrm{mL}$ of anti-Hib PS antibody. Preopsonization of $\mathrm{Hib}$ with complement and $10 \%$ heat-activated agammaglobulinemic serum added instead of immune serum yielded uptake of 9 to $19 \%$ compared to control and was considered background in the assay. After subtraction of background, the results of the opsonic assay were expressed as 100 times the ratio of uptake of Hib by PMN to uptake of control Hib preopsonized with complement and $10 \%$ immune serum pool.

Inhibition of anti-Hib PS antibody binding. IgG fractions were diluted to contain approximately $1 \mu \mathrm{g} / \mathrm{mL}$ of anti-Hib PS antibody and incubated with PBS or different concentrations of soluble Hib PS (range 0.01 to $10 \mu \mathrm{g} / \mathrm{ml}$ ) or cross-reacting Escherichia coli $\mathrm{K} 100$ PS (range $1-100 \mu \mathrm{g} / \mathrm{mL}$ ). The $E$. coli $\mathrm{K} 100$ PS was prepared from $E$. coli strain Easter, by the same method used to prepare Hib PS (27). The reaction vials were incubated at $37^{\circ} \mathrm{C}$ for $1 \mathrm{~h}$ and then overnight at $4^{\circ} \mathrm{C}$. The tubes were centrifuged $(1500 \times g$ for $5 \mathrm{~min})$ and anti-Hib PS antibody was measured in the supernate by the RABA. The results were expressed as the concentration of PS needed for $50 \%$ inhibition of anti-Hib PS antibody binding.

Functional affinity. The functional affinity, or avidity, of antibody to Hib PS was measured in the IgG fractions using a method modified after that described by Griswold et al. (9). In brief, a RABA was performed using $0.075 \mathrm{ng} / \mathrm{mL}$ of the radiolabeled Hib PS antigen instead of the usual concentration of 3.0 $\mathrm{ng} / \mathrm{mL}$ to insure that the antibody concentration was in excess. Also, to conform to the Griswold procedure, the RABA was modified to use a final vol of $70 \mu \mathrm{L}$ instead of $500 \mu \mathrm{L}(21)$, and an equal vol of saturated ammonium sulfate was used to precipitate antibody and antigen-antibody complexes instead of polyethylene glycol radioimmune precipitation (21). The fraction of bound antigen was calculated from counting the radioactivity of the pellets at different antibody dilutions. The avidity constant was given by the formula $\mathrm{Kav}=$ bound $/(1-$ bound $) \times[\mathrm{Ab}]$, where Kav is the avidity constant, bound is the fraction of bound antigen, and $[\mathrm{Ab}]$ is the concentration of anti-Hib PS antibody 
(mol wt $=150000$ ) as measured by the RABA assay using $3 \mathrm{ng} /$ $\mathrm{mL}$ of radiolabeled antigen, the usual concentration of antigen. The avidity constant was calculated at each dilution with bound values between 0.2 and 0.8 . The avidity value for the IgG fraction was determined by the mean of the values calculated at each dilution.

\section{RESULTS}

Table 1 summarizes the anti-Hib PS antibody concentrations in sera obtained before, 1 mo after vaccination, and 12 to $20 \mathrm{mo}$ after vaccination from the four subjects. Sera from the late bleeds were used in our analysis of functional activity described below. Total antibody concentrations in these sera ranged between 8.0 and $10.6 \mu \mathrm{g} / \mathrm{mL}$. There were no consistent differences in the relative proportions of $\mathrm{IgG}$ or $\mathrm{IgA}$ antibody to total anti-Hib PS antibody, or in the respective ratios of $\operatorname{IgG} 1$ to $\operatorname{IgG} 2$ antibody in the NK and $\mathrm{K}$ sera (Table 1). The concentrations of IgA antiHib PS antibody were low in all four sera (Table 1).

The effect of inoculum size on the bactericidal activity of each of the sera was evaluated using $20 \%$ agammaglobulinemic serum as a complement source, and test sera diluted to contain $2 \mu \mathrm{g} /$ $\mathrm{mL}$ of anti-Hib PS antibody (Fig. 1). With an inoculum of $\sim 3 \times$ $10^{3} \mathrm{cfu} / \mathrm{mL}$ of Hib strain Eagan, all four sera had equivalent bactericidal activity. But, with inocula between $10^{5}$ to $10^{6} \mathrm{cfu} /$ $\mathrm{mL}$ (the concentration of bacteria used in our initial screening assay), the two $\mathrm{K}$ sera killed 4 logs more Hib than the two NK sera. Virtually identical results were obtained with Hib strain MinnA (data not shown). An inoculum of $\sim 10^{6} \mathrm{cfu} / \mathrm{mL}$ of strain Eagan or MinnA was chosen for subsequent studies of bactericidal activity.

IgG fractions were prepared by Sepharyl S-300 chromatography of each of the four sera. Column fractions, containing no detectable IgM or IgA anti-Hib PS antibody by ELISA, were pooled. The resulting $\operatorname{IgG}$ fractions contained $<1 \%$ of total $\operatorname{IgM}$ and $<2 \%$ of total IgA as determined by nephelometry. Affinitypurified anti-Hib PS antibody was then prepared from each of the four IgG fractions using an Hib PS Sepharose column as described in the Materials and Methods. The respective ratios of $\mathrm{IgG} 1$ to $\mathrm{IgG} 2$ in the affinity-purified antibodies, as determined by ELISA, corresponded closely to the ratios of IgG1 and $\operatorname{IgG} 2$ antibody measured in the original sera (Table 1).

Complement-mediated bactericidal activity was measured in the respective sera, IgG fractions, and IgG affinity-purified antibodies (Fig. 2). Before the assay, the anti-Hib PS antibody concentrations were measured and adjusted according to the results of the RABA so that each fraction contained $2 \mu \mathrm{g} / \mathrm{mL}$ of anti-Hib PS antibody. The inoculum was $10^{6} \mathrm{cfu} / \mathrm{mL}$ of $\mathrm{Hib}$ strain Eagan. [Virtually identical results were obtained with strain MinnA (data not shown).] The respective IgG fractions and IgG affinity-purified antibodies prepared from sera of subjects NK1 , and K-1 and K-2 had bactericidal activity similar to that found in the corresponding original sera (Fig. 2). However, the respec- tive IgG and affinity purified anti-Hib PS antibody fractions from the serum of subject NK-2 had somewhat greater bactericidal activity than the original sera but still showed more than 3 logs less killing than the IgG fractions from the $\mathrm{K}-1$ and $\mathrm{K}-2$ sera.

No bactericidal activity was demonstrated in any of the NK or $\mathrm{K}$ sera or corresponding IgG fractions after absorption on a Hib PS-Sepharose column, a result indicating that at the antiHib PS antibody concentrations tested, any anti-noncapsular antibodies present in the sera or IgG fractions were not contributing to the bactericidal activity.

The effect of preopsonization with $25 \%$ complement and different concentrations of $\operatorname{IgG}$ affinity-purified anti-Hib PS antibody on the uptake of radiolabeled Hib cells by human PMN is demonstrated in Figure 3. The IgG antibodies isolated from the two K sera induced greater uptake of Hib by PMN than IgG antibodies from NK-1 and NK-2 sera. The concentrations of IgG anti-Hib PS required for $50 \%$ control uptake of Hib were 1.4 and $0.6 \mu \mathrm{g} / \mathrm{mL}$ for the antibodies prepared from the two Ksera, and 3.5 , and $>4 \mu \mathrm{g} / \mathrm{mL}$, respectively, for the two NK antibodies. Also, the percent uptake of Hib preopsonized with 2 $\mu \mathrm{g} / \mathrm{mL}$ of IgG affinity purified anti-Hib PS antibody paralleled the results of measurement of complement-dependent bactericidal activity using the same concentrations of antibody (Table 2).

The basis for assigning values for the antibody concentrations of the sera and IgG fractions is the antigen-binding equivalence to dilutions of a reference serum pool obtained from the Office of Biologics (36). Previous studies suggest that the slopes of binding-dilution curves of some antibodies to Hib PS may vary and, thus, affect the assigned antibody concentration as determined by RABA (36) or ELISA (37). Therefore, each of the IgG fractions was diluted to contain $\sim 1.6 \mu \mathrm{g} / \mathrm{mL}$ of antibody to $\mathrm{Hib}$ PS as determined by the RABA, and the slopes of the respective binding-dilution curves obtained by RABA were compared to that obtained with dilutions of the Office of Biologics reference serum (Fig. 4A). A similar experiment was performed with the ELISA (Fig. $4 B$ ), but the starting antibody concentrations were lower $(\sim 0.1 \mu \mathrm{g} / \mathrm{mL})$. By both assays, the respective bindingdilution curves of the $\operatorname{IgG}$ antibodies from the four subjects were very similar and were parallel to that of the reference serum. Also, before dilution, there was good agreement between the respective antibody concentrations assigned to the individual fractions by ELISA or RABA (compare ELISA to RABA-1, regular antigen concentration, Table 3).

Antigenic fine specificity of the NK and $\mathrm{K}$ antibodies was evaluated by measuring the ability of different concentrations of soluble Hib PS or cross-reacting $E$. coli K100 PS to inhibit binding of IgG fractions to radiolabeled Hib PS. The Hib PS concentrations that inhibited $50 \%$ binding were 0.15 and 0.17 $\mu \mathrm{g} / \mathrm{mL}$, respectively, for IgG fractions from NK-1 and NK-2; and 0.15 and $0.10 \mu \mathrm{g} / \mathrm{mL}$ for IgG fractions from subjects $\mathrm{K}-1$ and $\mathrm{K}-2$. Hib PS binding to the purified $\mathrm{IgG}$ antibodies was not

Table 1. Serum anti-Hib PS antibody concentrations*

\begin{tabular}{|c|c|c|c|c|c|c|c|}
\hline \multirow[b]{2}{*}{ Subject } & \multirow{2}{*}{$\begin{array}{c}\text { Preimmune } \\
\text { Total } \\
(\mu \mathrm{g} / \mathrm{mL})\end{array}$} & \multirow{2}{*}{ 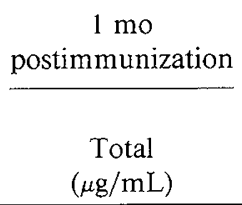 } & \multicolumn{5}{|c|}{ 12-20 mo postimmunization } \\
\hline & & & $\begin{array}{c}\text { Total } \\
(\mu \mathrm{g} / \mathrm{mL})\end{array}$ & $\begin{array}{c}\operatorname{IgA} \\
(\mathrm{U} / \mathrm{mL})\end{array}$ & $\begin{array}{c}\mathrm{IgG} \\
(\mu \mathrm{g} / \mathrm{mL})\end{array}$ & $\begin{array}{c}\text { Ratio } \\
\text { IgG1:IgG2 }\end{array}$ & $\begin{array}{c}\text { IgG affinity-purified } \\
\text { anti-Hib PS } \\
\text { antibody IgG1:IgG2† }\end{array}$ \\
\hline NK-1 & 0.9 & 20.5 & 8.0 & 0.5 & 5.8 & 0.5 & 0.6 \\
\hline NK-2 & 1.5 & 9.2 & 8.6 & 0.5 & 4.4 & 2.4 & 3.2 \\
\hline $\mathrm{K}-1$ & 7.5 & 21.5 & 8.0 & 0.4 & 9.0 & 4.1 & 6.0 \\
\hline $\mathrm{K}-2$ & 5.5 & 18.5 & 10.6 & 0.5 & 6.5 & 0.4 & 0.3 \\
\hline
\end{tabular}

* Total anti-Hib PS antibody was measured by RABA. IgA, IgG, IgG1, and IgG2 anti-Hib PS antibody were measured by ELISA. 1 unit of IgA antibody is $\sim 1 \mu \mathrm{g}$ (see Materials and Methods).

$\dagger$ Affinity-purified anti-Hib PS antibody was prepared from the respective IgG fractions that were prepared from sera obtained at 12 to 20 mo postimmunization (see Materials and Methods). 


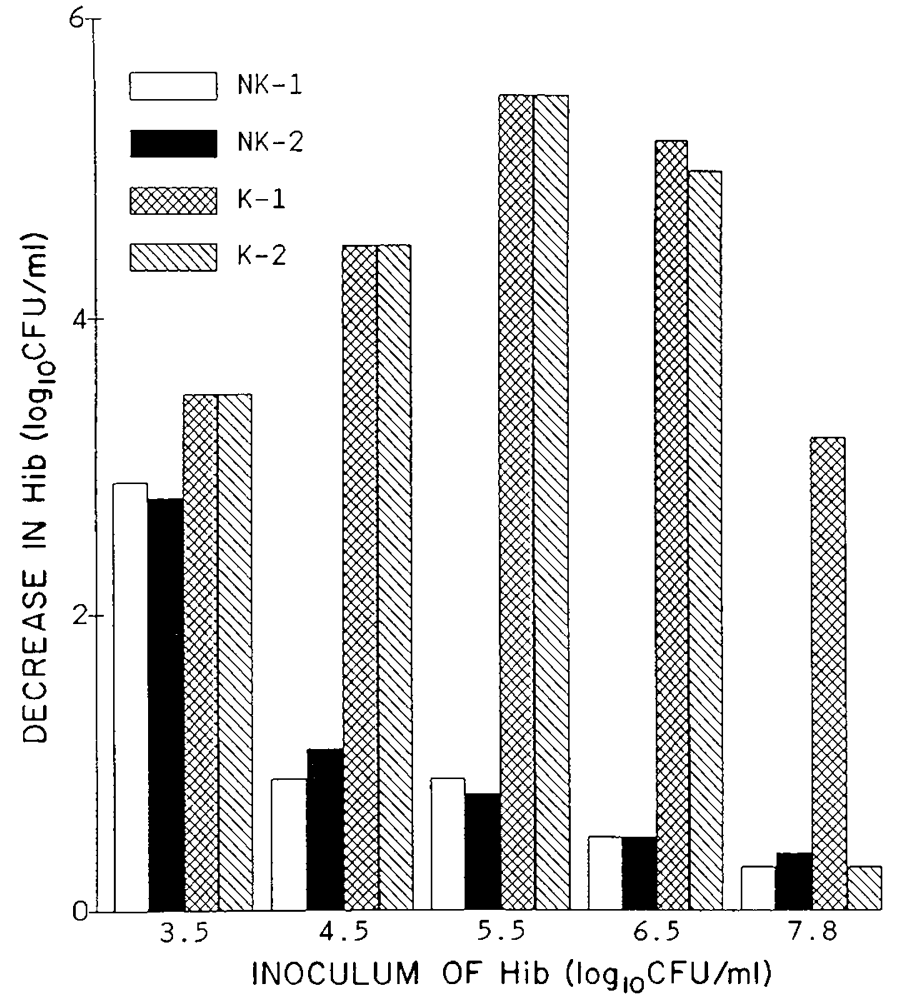

Fig. 1. Effect of inoculum size on survival of Hib cells (strain Eagan) in the presence of serum and complement. Each test serum was diluted to contain $2 \mu \mathrm{g} / \mathrm{mL}$ of anti-Hib PS antibody and was assayed with $20 \%$ complement. The results are expressed as the mean of two assays.

significantly inhibited by $E$. coli $\mathrm{K} 100$ polysaccharide (concentrations of $100 \mu \mathrm{g} / \mathrm{mL}$ inhibited $<15 \%$ antibody binding). As another measure of $\mathrm{V}$ region structure, we also assayed crossreactive idiotype expression as defined by inhibition of anti-Hib PS antibody binding to radiolabeled Hib PS by a goat antiidiotype previously described (38). Inhibition of 30 and $50 \%$ was detected in IgG from subjects NK-1 and NK-2, respectively; and 70 and $30 \%$ in $\mathrm{K}-1$ and $\mathrm{K}-2$. Thus, the range of cross-reactive idiotype expression was similar in NK and $\mathrm{K}$ antibodies.

The functional affinities (avidity) of the IgG anti-Hib PS antibodies are presented in Table 3. The IgG antibodies of subjects NK- 1 and NK-2 had lower avidity constants $(0.59$ and $1.03 \mathrm{nM}^{-1}$ ) compared to the $\mathrm{IgG}$ antibodies from the sera of the two $\mathrm{K}$ subjects ( 2.17 and $\left.3.35 \mathrm{nM}^{-1}\right)$. We also measured avidity in the sera from the NK and $K$ subjects, and in sera from five additional immunized adults selected because of $>4$ log killing in the original screening bactericidal assay. The avidity constants measured in the sera of the two NK and two K subjects were similar to those of the respective IgG fractions $(r=0.98)$. Further, the sera from the five additional adults with good serum bactericidal activity all had anti-Hib PS antibodies of high avidity (mean avidity constant $=2.70 \mathrm{nM}^{-1}$; range $=1.75$ to 5.6 ). The antibodies present in the Haemophilus influenzae reference serum from the Office of Biologics also had a high avidity constant (mean $\pm \mathrm{SE}=4.08 \pm 0.28 \mathrm{nM}^{-1}$ as measured in five assays).

Previous studies have shown that the results of the RABA are dependent on the assay conditions, and tend to be more affinitydependent when measured at low concentrations of radiolabeled antigen that at high antigen concentrations $(9,36)$. The effect of performing the RABA under different conditions on the antibody concentrations assigned to each of the $\operatorname{IgG}$ fractions is shown in Table 3. With the RABA-2 [used for determination of avidity by the Griswold method (9)], using 1:40 of the usual Hib PS antigen concentration resulted in markedly lower antibody concentrations assigned to the IgG fractions from NK-1 and NK-2 but

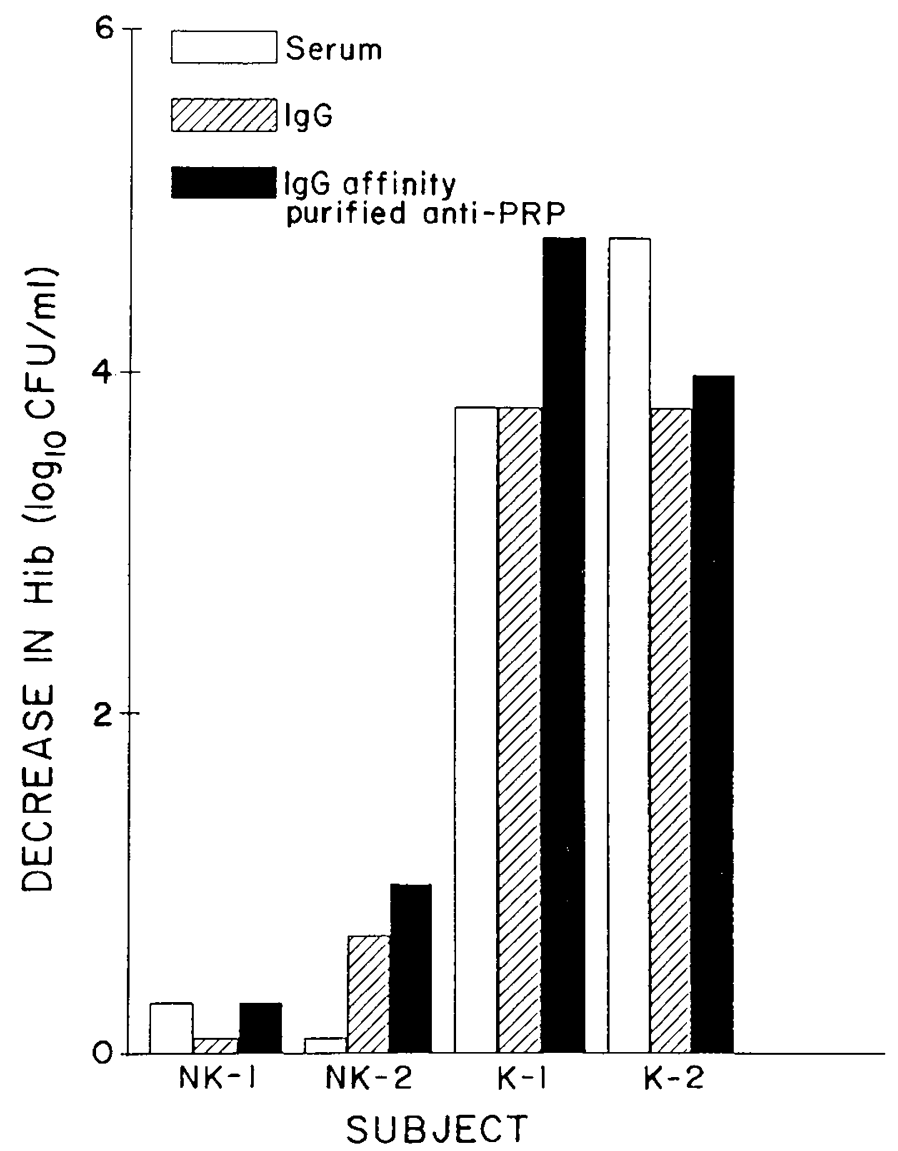

Fig. 2. Bactericidal activity of serum, IgG fractions or IgG affinitypurified anti-Hib PS antibody on survival of $\mathrm{Hib}$ cells in the presence of complement. Sera or fractions were diluted to contain $2 \mu \mathrm{g} / \mathrm{mL}$ of antiHib PS antibody. The reaction mixture contained $20 \%$ complement and $\sim 10^{6} \mathrm{cfu} / \mathrm{mL}$ of Hib cells (strain Eagan). The results are expressed as mean of two assays.

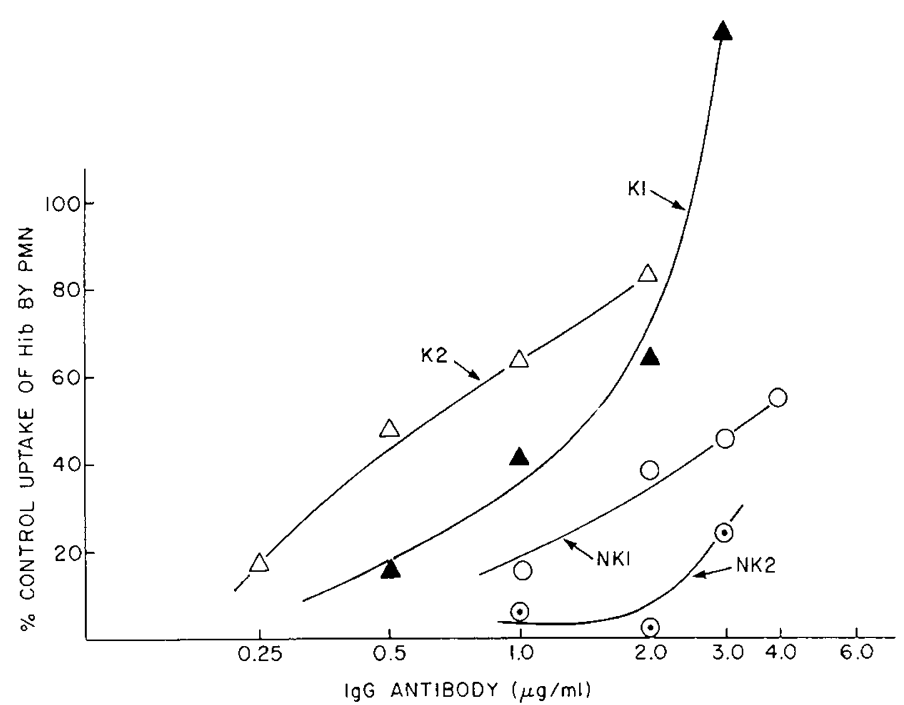

Fig. 3. Representative experiment showing the effect of preopsonization of radiolabeled Hib cells (strain MinnA) with different concentrations of IgG affinity-purified anti-Hib PS antibody, and 25\% complement on uptake of bacteria by PMN. After subtracting background, the results are expressed as 100 times the ratio of uptake of Hib to uptake of control Hib preopsonized with complement and $10 \%$ immune serum pool, assumed to yield $100 \%$ uptake (see Materials and Methods) 
Table 2. Summary of measurement of complement-mediated bactericidal and opsonic activity

\begin{tabular}{|c|c|c|c|c|c|}
\hline \multirow[b]{3}{*}{ Subject } & \multicolumn{4}{|c|}{ Bactericidal activity (log decrease)* } & \multirow{3}{*}{$\begin{array}{c}\text { Opsonic activity } \\
(\% \text { uptake }) \dagger\end{array}$} \\
\hline & \multicolumn{2}{|c|}{ Serum } & \multicolumn{2}{|c|}{$\begin{array}{l}\text { IgG anti-Hib } \\
\text { PS antibody }\end{array}$} & \\
\hline & Eagan $\ddagger$ & MinnAf & Eagan & MinnA & \\
\hline NK-1 & 0.3 & 0.3 & 0.3 & -0.3 & $20 \pm 15$ \\
\hline NK-2 & 0.1 & 0.1 & 1.0 & 1.6 & $13 \pm 11$ \\
\hline $\mathrm{K}-1$ & 3.8 & 4.3 & 4.8 & $>5.0$ & $62 \pm 16$ \\
\hline $\mathrm{K}-2$ & 4.8 & 3.9 & 4.0 & 3.7 & $93 \pm 23$ \\
\hline
\end{tabular}

${ }^{*} \mathrm{Log}$ decrease of Hib cells $/ \mathrm{mL}$ after 1 -h incubation with $2 \mu \mathrm{g} / \mathrm{mL}$ of anti-Hib PS antibodies and $20 \%$ agammaglobulinemic serum as a complement source. The results represent the mean of two assays.

$\dagger$ After subtraction of background, the percent uptake by PMN of Hib strain MinnA preopsonized with $2 \mu \mathrm{g} / \mathrm{mL}$ of antibody is compared to preopsonization with immune serum pool, assumed to yield $100 \%$ uptake (see Materials and Methods). The complement concentration was $25 \%$. The results are expressed as mean \pm SD of three assays.

$\ddagger$ Hib strain designations (see Materials and Methods).

only a modest or no decrease was observed in the concentrations assigned to the fractions from $\mathrm{K}-1$ and $\mathrm{K}-2$. With the RABA-1 (our usual assay), similar respective trends were observed with each of the fractions when tested at the two antigen concentrations, but the relative differences between the individual NK and $\mathrm{K}$ fractions were less than when measured by the RABA-2.

\section{DISCUSSION}

In this study, the activity of antibodies to Hib PS from the sera of vaccinated adults was compared using RABA, ELISA, and functional assays of bactericidal and opsonic activity. Postvaccination sera from two healthy individuals with 20.5 and 9.2 $\mu \mathrm{g} / \mathrm{mL}$ of antibodies to Hib PS failed to kill Hib when tested at $20 \%$ concentration, using agammaglobulinemic serum as an external complement source and an inoculum of $10^{6} \mathrm{cfu} / \mathrm{mL}$. Musher et al. (16), using a similar assay, also found low bactericidal activity in sera of some adults immunized with Hib PS. In our study, this phenomenon is shown to be related, in part, to the ratio of antibody molecules to the number of microorganisms present in the reaction mixture. When assayed with $3 \times 10^{3} \mathrm{cfu} /$ $\mathrm{mL}$ of $\mathrm{Hib}$, all of the sera had effective bactericidal activity. But, with $10^{6} \mathrm{cfu} / \mathrm{mL}$ [the inoculum used by Musher et al. (16)], only the $\mathrm{K}$ sera had $>3$ logs of killing (fig. 1). Thus, at antibody to cfu ratios of $\sim 600 \mathrm{pg} / \mathrm{cfu}$, the serum bactericidal activity of the four sera appeared similar but at limiting dilutions between 0.6 and $6 \mathrm{pg} / \mathrm{cfu}$, marked differences became apparent. The assay conditions that correlate best with the in vivo situation are currently undefined. In the present study, a high inoculum assay with a ratio of $0.6 \mathrm{pg} / \mathrm{cfu}$ was chosen for further evaluation because it best demonstrated the differences in functional activity among the individual sera. Although only low numbers of bacteria are likely to be encountered during the initial phase of bloodstream invasion in children, the low concentrations of complement and antibody per bacteria present in the high inoculum bactericidal assay may be encountered in infected body fluids such as cerebrospinal fluid (40).

Besides low bactericidal activity, the IgG antibody from the two NK subjects also had lower complement-mediated opsonic activity than antibodies of the two $\mathrm{K}$ subjects (Fig. 3). We considered a number of possible reasons for the lower bactericidal and opsonic activity of the $\mathrm{IgG}$ antibodies in the NK sera.

A prozone phenomenon (16) was ruled out by diluting the sera and IgG fractions of the NK subjects further without any increase in bactericidal activity (data not shown). The presence of noncomplement-activating antibodies may block the complement-mediated bactericidal activity of $\operatorname{IgG}$ antibody (41-43).
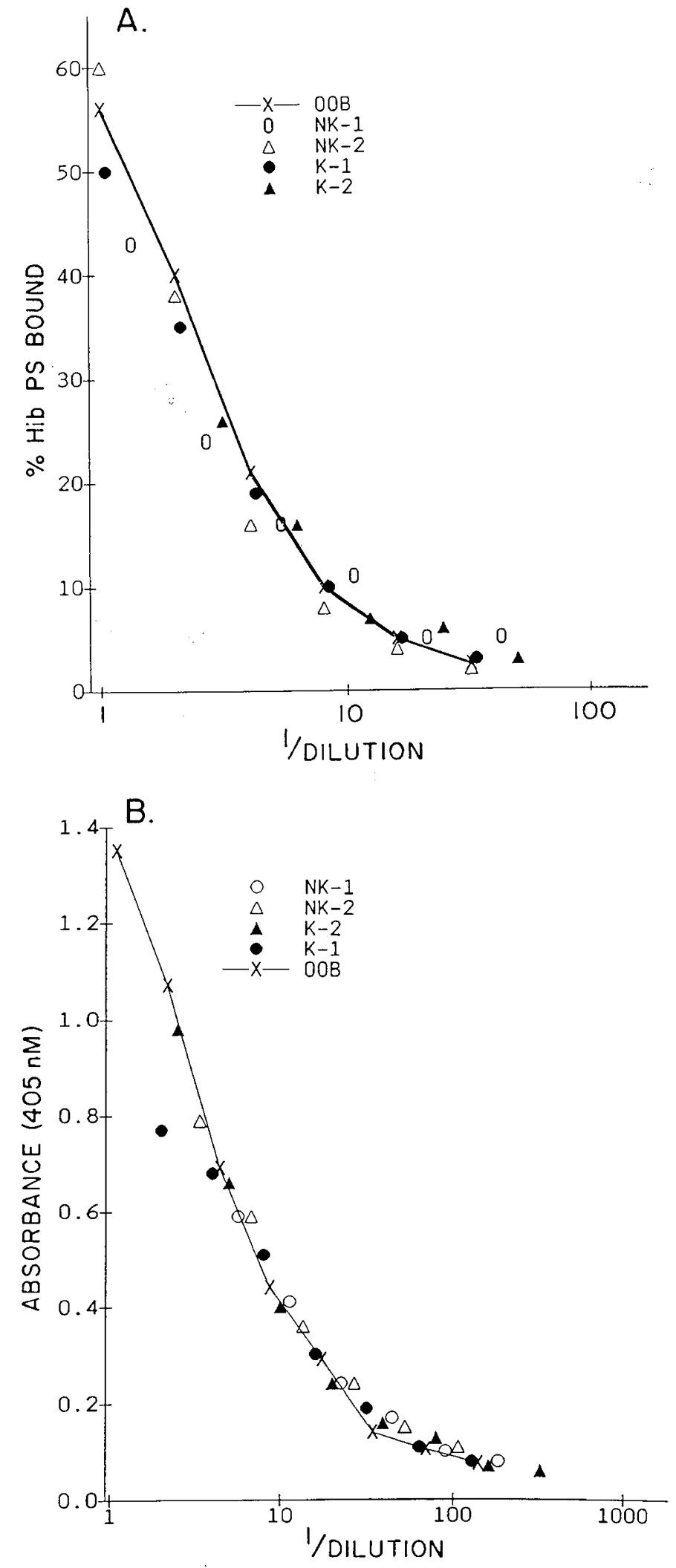

Fig. 4. Binding-dilution curves of $\mathrm{IgG}$ fractions from sera of each of the $\mathrm{NK}$ and $\mathrm{K}$ subjects in relation to the binding dilution curve of the Office of Biologics $H$. influenzae type b reference serum. $A, \mathrm{RABA}$. IgG fractions and reference serum were diluted to contain $\sim 1.6 \mu \mathrm{g} / \mathrm{mL}$ of total anti-Hib PS antibody as determined by RABA using $3 \mathrm{ng} / \mathrm{mL}$ of radiolabeled antigen. Percent of bound radioantigen was then measured in serial 2-fold dilutions. $B$, IgG ELISA. The IgG fractions and reference sera were diluted to contain $\sim 0.1 \mu \mathrm{g} / \mathrm{mL}$ of IgG anti-Hib PS antibody as determined by ELISA. Antigen-binding as determined by absorbance 405 was then measured in serial 2-fold dilutions. 
Table 3. Relation of avidity of IgG anti-Hib PS antibody to measurement of antibody concentrations by RABA using different concentrations of rabiolabeled Hib PS*

\begin{tabular}{ccccc}
\hline & \multicolumn{3}{c}{$\begin{array}{c}\text { Anti-Hib PS antibody concentrations } \\
(\mu \mathrm{g} / \mathrm{mL})\end{array}$} \\
\cline { 2 - 4 } $\begin{array}{c}\text { IgG } \\
\text { fraction }\end{array}$ & $\begin{array}{c}\text { IgG } \\
\text { ELISA }\end{array}$ & \multicolumn{2}{c}{ RAB antigen $/$ low } & \multicolumn{1}{c}{$\begin{array}{c}\text { Avidity, } \mathrm{nM}^{-1} \\
(\text { mean } \pm \mathrm{SE}) \dagger\end{array}$} \\
\hline NK-1 & 5.0 & $4.7 / 1.9$ & $2.0 / 0.31$ & $0.59 \pm 0.09$ \\
NK-2 & 3.8 & $4.4 / 2.0$ & $3.2 / 0.84$ & $1.03 \pm 0.19$ \\
K-1 & 5.8 & $4.8 / 3.2$ & $3.8 / 2.3$ & $2.17 \pm 0.30$ \\
K-2 & 5.5 & $4.8 / 3.9$ & $3.6 / 4.6$ & $3.35 \pm 1.1$ \\
\hline
\end{tabular}

* Concentrations of anti-Hib PS antibody were determined by using either $3.0 \mathrm{ng} / \mathrm{mL}$ of radiolabeled antigen (regular concentration), or $0.075 \mathrm{ng} / \mathrm{mL}$ (low concentration). The RABA-1 used $50 \mu \mathrm{L}$ of $\mathrm{IgG}$ in a final reaction vol of $500 \mu \mathrm{L}$, and polyethylene glycol for precipitation of antibody and antigen-antibody complexes. The RABA-2, used to determine avidity (9), used $50 \mu \mathrm{L}$ of $\mathrm{IgG}$ in a final reaction vol of $70 \mu \mathrm{L}$, and ammonium sulfate radioimmunoprecipitation. The Office of Biologics reference serum was used for the standard curve, and antibody concentrations were calculated from the percent binding of a dilution of $\mathrm{IgG}$ fraction binding between 40 and $60 \%$ of added antigen (a linear portion of the curve).

$\dagger$ Values shown represent the means of three to four assays except for $\mathrm{K}-2$ (two assays).

Previously, IgA anti-Hib PS antibodies were shown to have low bactericidal activity (7), and $\operatorname{IgA}$ antibodies have been reported to block bactericidal activity to Neisseria meningitidis $(41,42)$. Preliminary data also suggest that IgG2 or IgG4 antibody to Psuedomonas aeruginosa lipopolysaccharide is nonopsonic and may block the activity of $\mathrm{IgG1}$ or IgG3 antibodies (44). We considered blocking IgA antibody an unlikely explanation for the poor functional activity of the two NK sera because the respective $\mathrm{IgG}$ fractions and $\mathrm{IgG}$ affinity-purified anti-Hib PS antibodies also had low bactericidal activity (Fig. 2; Table 2). However, we cannot rule out the possibility of the presence of $\mathrm{IgG} 2$ or IgG4 blocking antibodies in the NK fractions.

In a previous study, using an assay inoculum of $\sim 10^{3} \mathrm{cfu} / \mathrm{mL}$, IgGl antibody to Hib PS was found to be about twice as effective in activating complement-mediated bacteriolysis of $\mathrm{Hib}$ than IgG2 antibody (13). We recently have extended these observations to examine complement-mediated bactericidal activity of clonally purified IgG1 and IgG2 antibodies to Hib PS, using different inocula of Hib (45). With $10^{6} \mathrm{cfu} / \mathrm{mL}$, we observed 2 to 3 logs greater bacterial killing with $\operatorname{IgG} 1$ than $\operatorname{IgG} 2$ antibodies. Thus, the predominance of $\mathrm{IgG} 2$ antibody in the $\mathrm{IgG}$ antibody response of NK-1 may, in part, have contributed to this low serum bactericidal activity. However, subject $\mathrm{K}-2$ also had a predominant IgG2 antibody response (Table 1), and both the sera and purified $\operatorname{IgG}$ antibodies showed effective bactericidal activity. Therefore, other factors must also contribute to the differences in the bactericidal activity observed with the NK and $\mathrm{K}$ antibodies.

We considered the possibility that the differences in functional activity between the NK and K sera might reflect differences in fine antibody specificity. As a first approach we examined the ability of different concentrations of $\mathrm{Hib}$ and $E$. coli $\mathrm{K} 100$ polysaccharides to inhibit binding of IgG antibody to radiolabeled Hib PS (10). However, all four of the IgG fractions were inhibited by low concentrations of Hib PS, but not by $>1000$ fold higher concentrations of K100. Thus, these assays for fine antigenic specificity of the variable-region did not reveal consistent differences. There also were no differences between the antibodies present in the $\mathrm{NK}$ and $\mathrm{K}$ IgG fractions in the range of cross-reactive idiotype expression as determined by inhibition of antigen-binding by a goat antiidiotype serum (38).

The IgG antibodies in the two NK sera were found to have low avidity (Table 3 ). Also, when these IgG fractions were remeasured by the RABA using $1 / 40$ of the usual concentration of radiolabeled antigen (i.e. at antibody excess), lower values for the antibody concentrations were obtained (Table 3). Had these lower values been assigned to these IgG fractions, the antibodies would have appeared to have had much greater functional activity per $\mu \mathrm{g}$. Interestingly, contrary to the prediction (36), the slopes of the binding-dilution curves of these low avidity antibodies were not significantly different from those of the high avidity antibodies when assayed by our standard RABA or ELISA (Figs. $4 A$ and $B$ ). The data from the ELISA confirm previous suggestions that the results obtained by ELISA may be relatively independent of antibody avidity, depending on the conditions of the assay (such as epitope density or serum dilution tested) (37). The avidity-independence of our ELISA may also explain the good agreement between the results of the RABA when performed with our usual antigen concentration and the IgG ELISA in measuring the respective antibody concentrations in the IgG fractions (Table 3).

Our routine RABA (RABA-1) was adapted from that described by Kuo et al. (21). Testing replicate samples, we have compared our results to those obtained at a number of other laboratories including the National Public Health Institute, Helsinki, Finland; Praxis Biologics (Rochester, NY), and Merck Sharp and Dohme Research Laboratories (West Point, PA). In each comparison, there was a high degree of concordance between the respective results $(46,47)$ (Granoff DM, unpublished data). In our study, the RABA-2 was used to determine radioantigen binding for calculation of avidity (9). This assay uses $50 \mu \mathrm{L}$ of the test sample in a final reaction volume of $70 \mu \mathrm{L}$ instead of $500 \mu \mathrm{L}$ used in the RABA-1. Also, the RABA-2 uses ammonium sulfate for radioimmune precipitation instead of polyethylene glycol (21). As shown in Table 3, both the RABA-1 and the RABA-2 appear to detect antibodies of low avidity, particularly when the regular antigen concentration is used. However, with the low concentration of antigen, the RABA-2 appears more insensitive than the RABA-1 for detection of low avidity antibodies. The reason for this difference is not known but may relate to the greater antibody concentration present in the RABA-2 reaction vial because of the smaller volume of diluent used. These data emphasize the importance of previous suggestions that the conditions of the RABA can markedly influence the anti-Hib PS antibody concentrations assigned to a serum $(9,36,39)$, particularly if the antibody is of low avidity (9).

Finally, our results also suggest that measurements of antibody avidity may help predict the functional activity of antibody to $\mathrm{Hib}$ PS. If so, these results have important implications for assessing immune responses to Hib PS in children. Data recently presented suggest that immunized children may respond with lower avidity anti-Hib PS antibodies than immunized adults (48). Indeed, in preliminary studies of avidity and bactericidal activity of serum antibodies of infants 3 to 9 mo of age immunized with Hib PS outer membrane protein conjugate vaccine, we found that a high proportion of the children produced low avidity antibodies and that these antibodies were poor activators of complement-mediated bactericidal activity (Amir J, Liang X, Granoff DM, unpublished data).

In conclusion, the results of this study demonstrate heterogeneity in bactericidal and opsonic activity of vaccine-induced antibodies to Hib PS. Although measurement of total antibody concentrations by RABA or ELISA provides a good measure of the relative immunogenicity of different $\mathrm{Hib}$ vaccines, the results are not sufficient to predict functional and, possibly, protective activity of the antibodies. For this reason, studies of vaccine immunogenicity should also include measurements of isotype composition and functional activity. However, one problem in assessing antibody functional activity is that the assays are cumbersome to perform and difficult to standardize. Therefore, if further studies confirm a relationship between poor functional activity and low antibody avidity, then this latter measurement, 
which is relatively simple to perform, should prove useful in assessing vaccine immunogenicity.

Acknowledgments. The authors are indebted to Dr. Alex Lucas, Children's Hospital Oakland Research Institute, Oakland, CA for first suggesting to us the possible relationship between poor antibody functional activity and low antibody avidity and for providing helpful comments on the manuscript. Dr. K. Lynn Cates, Washington University, also provided helpful suggestions during the early phase of this investigation and provided critical comments on the manuscript. Venita Boelloeni and Katherine Sheetz provided expert technical assistance.

\section{REFERENCES}

1. Winkelstein JA, Moxon ER 1982 Role of complement in the host's defense against Haemophilus influenzae. In Sell SH, Wright PF (eds) Haemophilus influenzae. Epidemiology, Immunity and Prevention of Disease. Elsevier Biomedical, New York, pp 135-143

2. Robbins JB, Parke JC, Schneerson R, Whisnant JK 1973 Quantitative measurement of "natural" and immunization-induced Haemophilus influenzae type b capsular polysaccharide antibodies. Pediatr Res 7:103-110

3. Ambrosino D, Schreiber JR, Daum RS, Siber GR 1983 Efficacy of human hyperimmune globulin in prevention of Haemophilus influenzae type b disease in infant rats. Infect Immun 39:709-714

4. Käyhty H, Peltola H, Karanko V, Mäkelä PH 1983 The protective level of serum antibodies to the capsular polysaccharide of Haemophilus influenzae type b. J Infect Dis 147:1100

5. Anderson P 1984 The protection level of serum antibodies to the capsular polysaccharide of Haemophilus influenzae type b. J Infect Dis 149:1034

6. Santosham M, Reid R, Ambrosino D, Wolff MC, Almeido-Hill J, Priehs C, Aspery KM, Garrett S, Croll L, Foster S, Burge G, Page P, Zacher B, Moxon R, Siber GR 1987 Prevention of Haemophilus influenzae type b infections in high-risk infants treated with bacterial polysaccharide immune globulin. N Engl J Med 317:923-929

7. Schreiber JR, Barrus V, Cates KL, Siber GR 1986 Functional characterization of human IgG, IgM, and IgA antibody directed to the capsule of Haemophilus influenzae type b. J Infect Dis 153:8-16

8. Hetherington SV 1988 The intrinsic affinity constant (K) of anticapsular antibody to oligosaccharides of Haemophilus influenzae type b. J Immunol 140:3966-3970

9. Griswold WR, Lucas AH, Bastian JF, Garcia G 1989 Functional affinity of antibody to Haemophilus influenzae type $b$ polysaccharide. J Infect Dis 159:1083-1087

10. Tarrand JJ, Scott MG, Takes PA, Nahm MH 1989 Clonal characterization of the human $\mathrm{IgG}$ antibody repertoire to Haemophilus influenzae type b polysaccharide. Demonstration of three types of $\mathrm{V}$ regions and their association with $\mathrm{H}$ and L chain isotypes. J Immunol 142:2519-2526

11. Anderson P, Johnston RB, Smith DH 1972 Human serum activity against Haemophilus influenzae type b. J Clin Invest 51:31-38

12. Anderson P, Pichichero M, Edwards K, Porch CR, Insel R 1987 Priming and induction of Haemophilus influenzae type $\mathrm{b}$ capsular antibodies in early infancy by Dpo20, an oligosaccharide-protein conjugate vaccine. J Pediatr 111:644-650

13. Weinberg GA, Granoff DM, Nahm MH, Shackelford PG 1986 Functional activity of different IgG subclass antibodies against type b capsular polysaccharide of Haemophilus influenzae. J Immunol 136:4232-4236

14. Granoff DM, Boies EG, Munson Jr RS 1984 Immunogenicity of Haemophilus influenzae type $\mathrm{b}$ polysaccharide-diphtheria toxoid conjugate vaccine in adults. J Pediatr 105:22-27

15. Granoff DM, Chacko A, Lottenbach KR, Sheetz KE 1989 Immunogenicity of Haemophilus influenzae type b polysaccharide-outer membrane protein conjugate vaccine in patients who acquired Haemophilus disease despite previous vaccination with type b polysaccharide vaccine. J Pediatr 114:925933

16. Musher D, Goree A, Murphy T, Chapman A, Zahradnick J, Apicella M, Baughn R 1986 Immunity to Haemophilus influenzae type b in young adults: Correlation of bactericidal and opsonizing activity of serum with antibody to polyribosylribitol phosphate and lipooligosaccharide before and after vaccination. $J$ Infect Dis 154:935-942

17. Deveikis A, Ward J, Kim KS 1988 Functional activities of human antibody induced by the capsular polysaccharide or polysaccharide-conjugate vaccines against Haemophilus influenzae type b. Vaccine 6:14-18

18. Cates KL, Marsh KH, Granoff DM 1985 Serum opsonic activity after immunization of adults with Haemophilus influenzae type b-diphtheria toxoid conjugate vaccine. Infect Immun 48:183-189

19. Cates KL 1985 Serum opsonic activity for Haemophilus influenzae type b in infants immunized with polysaccharide-protein conjugate vaccines. J Infect Dis 152:1076-1077

20. Musher DM, Watson DA, Lepow ML, McVerry P, Hamill R, Baughn RE 1988 Vaccination of 18-month-old children with conjugated polyribosyl ribitol phosphate stimulates production of functional antibody to Haemophilus influenzae type b. Pediatr Infect Dis J 7:156-159
21. Kuo JS-C, Monji N, Schwalbe RS, McCoy DW 1981 A radioactive antigenbinding assay for the measurement of antibody to Haemophilus influenzae type b capsular polysaccharide. J Immunol Methods 43:35-47

22. Granoff DM, Shackelford PG, Pandey JP, Boies EG 1986 Antibody responses to Haemophilus influenzae type b polysaccharide vaccine in relation to $\mathrm{Km}(1)$ and $\mathrm{G} 2 \mathrm{~m}(23)$ immunoglobulin allotypes. $J$ Infect Dis 154:257-264

23. Shackelford PG, Granoff DM, Nelson SJ, Scott MG, Smith DS, Nahm MH 1987 Subclass distribution of human antibody to Haemophilus influenzae type b capsular polysaccharide. J Immunol 138:587-592

24. Scott MG, Nahm MH 1984 Mitogen-induced human IgG subclass expression. J Immunol 133:2454-2460

25. Madassery JV, Kwon OH, Lee SY, Nahm MH 1988 IgG subclass deficiency: IgG subclass assays and IgG2 concentrations among 8015 blood donors. Clin Chem 34:1407-1413

26. Madore DV, Johnson CL, Phipps DC, Pennridge Pediatric Associates, Popejoy LA, Eby R, Smith DH 1989 Safety and immunologic response to Haemophilus influenzae type $\mathrm{b}$ oligosaccharide- $\mathrm{CRM}_{197}$ conjugate vaccine in 1 - to 6 -month-old infants. Pediatrics (in press)

27. Kuo JS-C 1980 Combined Haemophilus influenzae type b and pertussis vaccine. United States Government Patient No. 4,196,192 issued April 1.

28. Munson RS Jr, Shenep JL, Barenkamp SJ, Granoff DM 1983 Purification and comparison of outer membrane protein P2 from Haemophilus influenzae type b isolates. J Clin Invest 72:677-684

29. Munson Jr RS, Grass S 1988 Purification, cloning, and sequence of outer membrane proteins P1 of Haemophilus influenzae type b. Infect Immun 56:2235-2242

30. Barenkamp SJ, Munson Jr RS, Granoff DM 1981 Subtyping isolates of Haemophilus influenzae type b by outer membrane protein profiles. J Infect Dis 143:668-676

31. Granoff DM, Sheetz K, Pandey JP, Nahm MH, Rambeck JH, Jacobs JL, Musser J, Selander RK, Kabeer M, Murphy TV, Osterholm MT 1989 Host and bacterial factors associated with Haemophilus influenzae type b disease in Minnesota children vaccinated with type $b$ polysaccharide vaccine. J Infect Dis 159:908-916

32. Barenkamp SJ, Granoff DM, Pittman M 1983 Outer membrane protein subtypes and biotypes of Haemophilus influenzae type b: relation between strains isolated in the 1934-1954 and 1977-1980. J Infect Dis 148:1127

33. Musser JM, Granoff DM, Pattison PE, Selander RK 1985 A population genetic framework for the study of invasive diseases caused by serotype b strains of Haemophilus influenzae. Proc Natl Acad Sci USA 82:5078-5082

34. Munson Jr RS, Granoff DM 1985 Purification and partial characterization of outer membrane proteins P5 and P6 from Haemophilus influenzae type b. Infect Immun 49:544-549

35. Newman SL, Waldo B, Johnston Jr RB 1973 Separation of serum bactericidal and opsonizing activities for Haemophilus influenzae type b. Infect Immun $8: 488-490$

36. Anderson P, Insel RA, Porcelli S, Ward JI 1987 Immunochemical variables affecting radioantigen-binding assays of antibody to Haemophilus influenzae type b capsular polysaccharide in childrens' sera. J Infect Dis 156:582-590

37. Steward MW, Lew AM 1985 The importance of antibody affinity in the performance of immunoassays for antibody. J Immunol Methods 78:173190

38. Lucas AH, Granoff DM 1990 A major cross-reactive idiotype associated with human antibodies to Haemophilus influenzae by polysaccharide: expression in relation to age and IgG subclass. J Clin Invest (in press)

39. Ward JI, Greenberg DP, Anderson PW, Burkhart KS, Christenson PD, Gordon LK, Kähyty H, Kuo JSC, Vella P 1988 Variable quantitation of Haemophilus influenzae type $\mathrm{b}$ anticapsular antibody by radioantigen binding assay. $\mathrm{J} C$ lin Microbiol 26:72-78

40. Feldman WE 1976 Concentration of bacteria in cerebrospinal fluid of patients with bacterial meningitis. J Pediatr 86:549-552

41. Griffiss J, Broud DD, Bertram MA 1975 Bactericidal activity of meningococcal antisera. Blocking by IgA of lytic antibody in human covalescent sera. J Immunol 114:1779-1784

42. Griffiss JM, Bertram MA 1977 Immunoepidemiology of meningococcal disease in military recruits. II. Blocking of serum bactericidal activity by circulating IgA early in the course of invasive disease. J Infect Dis 136:733-739

43. Gnehm HE, Pelton SI, Gulati S, Rice PA 1985 Characterization of antigens from nontypable Haemophilus influenzae recognized by human bactericidal antibodies. Role of Haemophilus outer membrane proteins. J Clin Invest 75:1645-1658

44. Moss R 1989 P. aeruginosa endobronchial infection in cystic fibrosis induces nonopsonic IgG2 and IgG4 lipopolysaccharide-specific antibodies. Pediatr Res 25:185A (abstr)

45. Amir J, Scott MG, Nahm M, Granoff DM 1990 Bactericidal and opsonic activity of IgG1 and $\operatorname{lgG} 2$ anticapsular antibodies against Haemophilus influenzae type $\mathrm{b}$. J Infect Dis (in press)

46. Weinberg GA, Granoff DM 1988 Polysaccharide-protein conjugate vaccines for the prevention of Haemophilus influenzae type $\mathrm{b}$ disease. $J$ Pediatr 113:621-631

47. Sullivan B, Madore DV, Granoff DM 1988 Interlaboratory comparison of PRP antibody titers as determined by radiolabeled antigen binding assay Pediatr Res 23:1095A (abstr)

48. Hetherington SV 1989 The affinity of anti-capsular polysaccharide antibody produced by children immunized with conjugated Haemophilus influenzae b capsular polysaccharide vaccines. Pediatr Res 25:1064A (abstr) 